\title{
Spectrum of pediatric malignancy- A cancer hospital-based study
}

Gupta V. ${ }^{\mathbf{1}}$, Kalraiya A. ${ }^{2 *}$, Mekle D. ${ }^{3}$

DOI: https://doi.org/10.17511/ijpr.2020.i01.05

\footnotetext{
1 Vidhi Gupta, Consultant, Department of Radiation Oncology, Jawaharlal Nehru Cancer Hospital, Bhopal, Madhya Pradesh, India.

2* Ashish Kalraiya, Associate Professor, Department of Paediatrics, Peoples Hospital, PCMS and RC, Bhopal, Madhya Pradesh, India.

3 Dinesh Mekle, Associate Professor, Department of Paediatrics, Peoples Hospital, PCMS and RC, Bhopal, Madhya Pradesh, India.
}

Objective: Childhood malignancy being a significant cause of mortality among children. The aim of the study is to find out the epidemiology of tumours in children in our region below $<14$ years age who presented to tertiary care Cancer hospital, Bhopal, M.P. for period of four years (2015- 2018). Methodology: All children with cancer, aged 1-14 years diagnosed by mean of histological and cytological examination during a period of 4 years were reviewed. Results: During the period of four years 275 patients were diagnosed as having paediatric malignancies. According to year wise distribution highest incidence of cases were found in 2016 (32.72\%). The highest number of cases, $96(35 \%)$ were in 10-14 years of age group and mean age was 7.43 with SD 4.0. Male were affected more than females with ratio of $2.66: 1$. It was observed that haematological malignancies were more common $172(62.54 \%$ ) than the non haematological malignancies $103(37.45 \%)$. Leukemia 150 (54.54\%) is most common pediatric cancer amongst which Acute lymphoblastic leukemia is most common haematological malignancy. Overall, it was found that most common cancer group in the present study were leukemia (54\%) followed by lymphoma (8.36\%), Brain tumours $(7.27 \%)$ and Sarcoma (7.27\%). Conclusion: Although the exact incidence rate cannot be provided by this hospital-based study, the information is useful in showing distribution patterns of childhood malignancy in this region.

Keywords: Childhood, Paediatric Malignancy, Tumours, Spectrum

Corresponding Author

Ashish Kalraiya, Associate Professor, Department of Paediatrics, Peoples Hospital, PCMS and RC, Bhopal, Madhya Pradesh, India.

Email: akalraiya@yahoo.com
How to Cite this Article

Gupta V, Kalraiya A, Mekle D. Spectrum of pediatric malignancy- A cancer hospital-based study. Pediatric Rev Int J Pediatr Res. 2020;7(1):27-31.

Available From

https://pediatrics.medresearch.in/index.php/ijpr/arti cle/view/572
To Browse

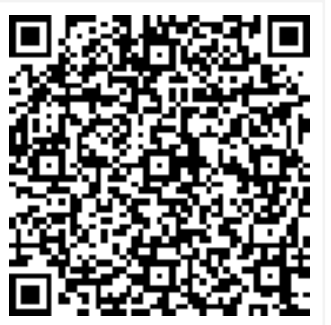

Manuscript Received 2020-01-08

Conflict of Interest No
Review Round 1 2020-01-18

Funding Nil

$\begin{gathered}\text { Review Round } 2 \\ 2020-01-24\end{gathered}$
Ethical Approval
Yes

Review Round 2

Yes
Review Round 3

Plagiarism X-checker $5 \%$
Accepted 2020-01-28

Note

(c) 2020 by Vidhi Gupta, Ashish Kalraiya, Dinesh Mekle and Published by Siddharth Health Research and Social Welfare Society. This is an Open Access article licensed under a Creative Commons Attribution 4.0 International License https://creativecommons.org/licenses/by/4.0/ unported [CC BY 4.0]. 


\section{Introduction}

Cancer in children can occur anywhere in the body, including the blood and lymph node, brain, spinal cord, kidney and other organs and tissue, Cancer begins when healthy cell change and grow out of control. In most type of cancer, these cells form a mass called a tumour. A tumour can be cancerous or benign. A cancerous tumour is malignant, meaning it can grow and spread to other part of the body. Tumors that occurs in children are as diverse as those in adult and present a number of challenges for pathologist [1].

Compared with cancers that occur in adult, childhood cancers are rare comprising only $1 \%$ of all the cancers [2]. More than $10 \%$ of all death in children below 15-years of age are caused by malignant diseases in the developed countries. In the developing world, cancers are yet to be recognized as a major pediatric illness, however they are fast emerging as a distinct entity to be dealt upon [3].

Cancer is leading cause of death for children and adolescents around the world and approximately 300,000 children aged $0-15$ years old are diagnosed with cancer each year [4]. Childhood malignancy being a significant cause of death among children. The aim of the study is to find out the spectrum of childhood ( $<14$ years) cancers in patients who presented to Jawaharlal Nehru Cancer hospital, Bhopal, M.P. for period of four years (2015- 2018).

\section{Material and Method}

Setting: This study was done in tertiary care Cancer hospital, Bhopal. M.P.

Duration: In this study four years data was collected from January 2015 to December 2018.

Type study: A cancer hospital based retrospective study.

Inclusion criteria: All children with cancer, aged 114 years diagnosed by mean of histological and cytological examination during four years period in JNCH (Jawaharlal Nehru Cancer Hospital), Bhopal were included in the study.

Exclusion criteria: All suspected cases but not confirmed pathologically.

Scoring system: The present study have followed ICCC (International childhood cancer classification) to classify the tumours.
In this retrospective study, four years of hospital records were used from January 2015 to December 2018. All children with cancer, aged 1-14 years diagnosed by mean of histological and cytological examination during that period in tertiary care hospital at Bhopal were included in the study. Patient from all over M.P. and Chhattisgarh and adjoining states attend this hospital for better cancer care and cure. Data was analyzed according to age, sex, and histopathological and cytological basis. All tumours were diagnosed on routine hematoxylin and eosin stained section; special stain and immunohistochemistry was applied wherever necessary. Fine needle aspiration cytology was done in some cases only. For the diagnosis of leukemia, complete blood count with peripheral smear examination, bone marrow aspiration and biopsy, flow cytometry was done to confirm the diagnosis. For children, the (International childhood cancer classification) was used based on morphology of the tumours and is composed of 12 main groups.

\section{Result}

During the period of four years 275 patients were diagnosed as having paediatric malignancies. According to year wise distribution highest incidence of cases were found in 2016(32.72\%) followed by 2017 (29.45\%), 2015 (25.45\%), 2018(12.36\%) (Table 1)

Table-1: Years wise distribution of childhood cancer.

\begin{tabular}{|l|l|l|}
\hline \multicolumn{1}{|c|}{ Years } & \multicolumn{1}{|c|}{ Number } & \multicolumn{1}{c|}{$\%$} \\
\hline 2015 & 70 & 25.45 \\
\hline 2016 & 90 & 32.72 \\
\hline 2017 & 81 & 29.45 \\
\hline 2018 & 34 & 12.36 \\
\hline
\end{tabular}

Tumours were arranged according to their age wise incidence in $1-4$ years $84(30.5 \%)$, 59years95(34.54\%), $10-14$ years 96 (35\%). The highest incidence was seen in 10-14years of age group and lowest in 1-4 years of age group

Table-2: Age wise distribution of childhood cancer.

\begin{tabular}{|l|l|}
\hline \multicolumn{1}{|c|}{ 1-year to 4 year } & \multicolumn{1}{|c|}{$\mathbf{8 4 ( 3 0 . 5 0 \% )}$} \\
\hline 5 -year to 9 year & $95(34.54 \%)$ \\
\hline 10 -year to14 year & $96(35 \%)$ \\
\hline
\end{tabular}

Mean age 7.43 with SD 4.09

It was found that $200(72.72 \%)$ Males were affected and $75(27.27 \%)$ Female. 
In the present study, it was found that the male were affected more than females a ratio of $2.66: 1$ (Table 3)

\section{Table-3: Sex wise distribution of cases.}

\begin{tabular}{|l|l|}
\hline \multicolumn{1}{|c|}{ Sex } & \multicolumn{1}{c|}{ Number } \\
\hline Male & $200(72.72 \%)$ \\
\hline Female & $75(27.27 \%)$ \\
\hline
\end{tabular}

Male / female ratio 2.66

It was observed that haematological malignancies were more common $172(62.54 \%)$ than the nonhaematological malignancies 103 (37.45\%). Leukemia $150(54.54 \%)$ is most common pediatric cancer amongst which Acute lymphoblastic leukemia is most common haematological malignancy. It accounts for $122(44.36 \%)$ of total malignancies and $71 \%$ of total haematological malignancies. Amongst haematological malignancies ALL is followed by AML 23(8.36\%), Non-Hodgkins Lymphoma 17 (6.18\%) and Hodgkin`s Lymphoma 6 $(2.18 \%)$ CML 5 (1.81\%). Most common Non haematological malignancy is Sarcoma 20 (7.27\%) and Brain tumours $20(7.27 \%)$ followed by Osteosarcoma 8 (2.90\%) Neuroblastoma 8 (2.90\%), Retinoblastoma $8 \quad(2.90 \%)$ Wilm`s tumours $6(2.18 \%)$

Table-4: Distribution of childhood cancer according to type and age (years).

\begin{tabular}{|l|l|l|l|l|}
\hline \multicolumn{1}{|c|}{ TYPE } & \multicolumn{1}{|c|}{ Total } & \multicolumn{1}{c|}{$1-4$} & \multicolumn{1}{c|}{$5-9$} & \multicolumn{1}{c|}{$10-14$} \\
\hline ALL & $122(44.36 \%)$ & $44(16 \%)$ & $45(16.35)$ & $33(12 \%)$ \\
\hline AML & $23(8.36)$ & $8(2.90)$ & $7(2.54)$ & $8(2.90)$ \\
\hline NHL & $17(6.18)$ & 0 & $10(3.63)$ & $7(2.54)$ \\
\hline HL & $6(2.18)$ & 0 & $3(1.09)$ & $3(1.09)$ \\
\hline CML & $5(1.81)$ & 0 & $2(0.73)$ & $3(1.09)$ \\
\hline Sarcoma & $20(7.27)$ & $2(0.73)$ & $10(3.63)$ & $8(2.90)$ \\
\hline Brain tumour & $20(7.27)$ & $4(1.45)$ & $6(2.18)$ & $10(3.63)$ \\
\hline Osteosarcoma & $8(2.90)$ & $1(0.36)$ & 0 & $7(2.54)$ \\
\hline Retinoblastoma & $8(2.90)$ & $3(1.09)$ & $5(1.81)$ & 0 \\
\hline Neuroblastomas & $8(2.90)$ & $5(1.81)$ & $3(1.09)$ & 0 \\
\hline Ewing`s sacoma & $7(2.90)$ & 0 & $2(0.73)$ & $5(1.81)$ \\
\hline Wilm`s tumour & $6(2.18)$ & $5(1.81)$ & $1(0.36)$ & 0 \\
\hline Cancer liver & $3(1.09)$ & $3(1.09)$ & 0 & 0 \\
\hline Cancer Nasophyrenx & $3(1.09)$ & 0 & 0 & $3(1.09)$ \\
\hline Cancer ovary & $3(1.09)$ & 0 & 0 & $3(1.09)$ \\
\hline Cancer lung & $2(0.73)$ & $1(0.36)$ & 0 & $1(0.36)$ \\
\hline Cancer Stomuch & $2(0.73)$ & $1(0.36)$ & $1(0.36)$ & 0 \\
\hline Cancer Testis & $2(0.73)$ & $2(0.73)$ & 0 & 0 \\
\hline Hepatoblastoma & $2(0.73)$ & $2(0.73)$ & 0 & 0 \\
\hline Germ cell tumour & $2(0.73)$ & 0 & 0 & $2(0.73)$ \\
\hline Rhabdomayosarcoma & $1(0.36)$ & $1(0.36)$ & 0 & 0 \\
\hline Spindle cell cancer & $1(0.36)$ & 0 & 0 & $1(0.36)$ \\
\hline
\end{tabular}

\begin{tabular}{|l|l|l|l|l|}
\hline Renal cell carcinoma & $1(0.36)$ & $1(0.36)$ & 0 & 0 \\
\hline APML & $1(0.36)$ & 0 & 0 & $1(0.36)$ \\
\hline PNET & $1(0.36)$ & $1(0.36)$ & 0 & 0 \\
\hline Spine secondary & $1(0.36)$ & 0 & 0 & $1(0.36)$ \\
\hline
\end{tabular}

\section{Discussion}

In $\mathrm{JNCH}$ during the period of four years 275 patients were diagnosed as having paediatric malignancies. In present study, it was observed that most common pediatric cancer cases diagnosed was leukemia (54.54\%) amongst which ALL (44.36\%) is most common of all malignancy. These results are similar to other studies. $[5,6,7,8,9]$.

It was found that most common cancer group in the present study were leukemia (54\%) followed by lymphoma $(8.36 \%)$, Brain tumours $(7.27 \%)$ and Sarcoma $(7.27 \%)$. This result is contrary to study done by Jabeen et al showed that Lymphoma $(24.2 \%)$ followed by Retinoblastoma (17.4\%), leukemia (14.3\%) [10]. Study by Munlima et al showed that most common cancer group was leukemia (26.9\%) followed by Retinoblastoma $(15.9 \%)$, CNS tumour (14.5\%), Lymphoma (13.1\%) [11].

In present study, it was observed that proportion of males $2.66 \%$ which were higher than studies by others $[7,12,10,13]$. Mean age in the present study was 7.43 with SD 4.09 which is slightly higher than study by Haleh et al [9].

In this study most of cases were in age group of 1014 years $(35 \%)$, Similar finding was seen in a study by Rajpal et al showed similar results in the age group of $10-14$ years (58.18\%) [14] .This result is contrary to study done by others in which most cases were between to 5-9 years age group $[7,11,15]$. Some Studies found most common age is $0-4$ years $[13,16]$. In the present study, all cases were $36 \%$ in $0-4$ years age group and found similar numbers in 5-9 years of age group]

The etiology of childhood cancers is largely unknown. Although genetic factors, environmental factors, maternal use of oral contraceptive pills, living in near to high voltage power line, ionizing radiation exposure during pregnancy, pesticide exposure in parents, parental occupation smoking are the factors [15]. Few environmental risk factors such as exposure to air pollutants and radiation play an important role in the incidences of childhood cancers [17]. Incidence of these cancers varies throughout the world with regard to age, gender, ethnicity, socioeconomic status and geography [7]. 
Apart from being retrospective study this study has the limitation this current study is a single institution based study restricted by a small sample size and hence this retrospective review cannot serve as a benchmark for reference, Hence further multi institutional studies over a longer duration of time needs to be done to serve as a benchmark for future.

\section{Conclusion}

Although the exact incidence rate cannot be provided by this single institution-based study, the information is useful in showing distribution pattern of childhood malignancy in this region. It is not possible to prevent cancer in children. The most effective way to reduce the incidence of cancer is to focus on a early and correct diagnosis followed by effective therapy. Programmes to promote early and correct diagnosis have been successfully used in countries of all income level, often through collaborative effort of government, civil society and non-government organization with vital roles played by parent group.

\section{What this study adds to existing knowledge?}

This study is a single institution-based study done in Jawahar Lal Nehru cancer hospital, Bhopal. This is oldest cancer hospital in this region and patients comes from all over the Madhya Pradesh, Chhattisgarh and adjoining areas, hence from the study, a representation of spectrum of various malignancies in this part of India was generated.

\section{Author's contribution}

Dr. Vidhi Gupta: Data collection, data analysis, literature search, drafted initial manuscript and approved the final manuscript before submission.

Dr. Ashish Kalraiya: Conceptualized the study, develop the study design, did literature search, data analysis, revised the manuscript and approved the final manuscript before submission.

Dr. Dinesh Mekle: Data analysis, literature search, revised the manuscript and approved the final manuscript before submission.

\section{Abbreviations}

\begin{tabular}{|l|l|}
\hline \multicolumn{1}{|c|}{ TYPE } & \multicolumn{1}{c|}{ Abbreviation } \\
\hline ALL & Acute lymphoblastic leukemia \\
\hline
\end{tabular}

\begin{tabular}{|l|l|}
\hline AML & Acute myeloid leukemia \\
\hline CML & Chronic myeloid leukemia \\
\hline NHL & Non- Hodgkin Lymphoma \\
\hline HL & Hodgkin Lymphoma \\
\hline -APML & Acute Promyelocytic leukemia \\
\hline PNET & Primitive Neuro Ectodermal tumour \\
\hline
\end{tabular}

\section{Reference}

01. Sharma S, Mishra K, Agrawal S, Khanna G. Solid tumors of childhood. Indian J Pediatr. 2004;71;501504. doi: 10.1007/BF02724289 [Crossref][PubMed] [Google Scholar]

02. Lanier AP, Holck P, Ehrsam Day G, Key C. Childhood cancer among Alaska Natives. Pediatr. 2003;112(5)e396. doi: 10.1542/peds.112.5.e396 [Crossref][PubMed][Google Scholar]

03. Kusumakumary $P$, Jacob $R$, Jothirmayi R, Nair MK. Profile of pediatric malignancies- $A$ ten years study. Indian Pediatr. 2000;37;1234-1238. [Crossref][PubMed][Google Scholar]

04. Steliarova-Foucher $E$, Colombet M, Ries LAG, Moreno $F$, Dolya A, Bray $F$, et al. International incidence of childhood cancer,2001-10- A population-based registry study. Lancet Oncol. 2017;18(6)719-731. doi: 10.1016/S14702045(17)30186-9 [Crossref][PubMed][Google Scholar]

05. Fethi A, Amani F, Bahadoram M. Epidemiology of childhood cancer in Northwest Iran. Asian Pac J Cancer Prevent. 2015;16(13)5459-5462. doi: 10.7314/APJCP.2015.16.13.5459

[Crossref]

[PubMed][Google Scholar]

06. Jafroodi M, Ghandi Y. Epidemiologic evaluation of pediatric malignancies in 17 shahrivar hospital. J Guilan Univ Med Sci. 2009;17(68)14-21. [Crossref] [PubMed][Google Scholar]

07. Ghasemi M, Karami $H$, Abedian-Kenari $S$, Kianifar S. Patterns of cancer in the children admitted in Avicenna Hospital in Sari, Iran. Int J Haematol- Oncol Stem Cell Res. 2011;5(2)29-33. [Crossref][PubMed][Google Scholar]

08. Das S, Paul DK, Anshu K, Bhakta S. Childhood cancer incidence in India between 2012 and 2014Report of a population - Based cancer Registry. Indian Pediatr. 2017;54(12)1033-1036. doi: 10.1007/s13312-017-1207-y [Crossref][PubMed] [Google Scholar] 
09. Arora RS, Eden T, Kapoor G. Epidemiology of childhood cancer in india. Indian J Cancer. 2009;46(4)264-273. doi: 10.4103/0019509X.55546 [Crossref][PubMed][Google Scholar]

10. Jabeen $\mathrm{S}$, Haque $\mathrm{M}$, Islam $\mathrm{MJ}$, Talukdar $\mathrm{M} \mathrm{H}$. Profile of pediatric malignancies- A five years study. J Dhaka Med Coll. 2010;19(1)33-38. doi: 10.3329/jdmc.v19i1.6249 [Crossref][PubMed] [Google Scholar]

11. Hazarika M, Krishnatreya M, Bhayan C, Saikia BJ, Kataki AC, Nandy $P$, et al. Overview of childhood cancers at a Regional cancer centre in North-East India. APJCP. 2014;15(18)7817-7819. doi: 10.7314/APJCP.2014.15.18.7817 [Crossref] [PubMed][Google Scholar]

12. Boroumand $H$, Moshki M, Khajavi A, Darabian M, Hashemizadeh $H$. Epidemiology of childhood cancer in Northeast of Iran. Iran J Ped Hematol Oncol. 2016;17(1)9-15. Available at [Article][Crossref] [PubMed][Google Scholar]

13. Bhalodia JN, Patel MM. Profile of pediatric Malgnancy- A three years study. Nat J Comm Med. 2011;2(1)24-27. [Crossref][PubMed][Google Scholar]
14. Punia RS, Mundi I, Kundu R, Jindal G, Dalal U, Mohan $H$. Spectrum of nonhematological pediatric tumors- A clinicopathologic study of 385 cases. Indian J Med Paediatr Onco. 2014;35(2)170-174. doi: 10.4103\%2F0971-5851.138995 [Crossref] [PubMed][Google Scholar]

15. Hashemizadeh $H$, Boroumand $H$, Noori $R$, Darabian $M$. Socioeconomic status and other characteristics in childhood leukemia. Iran J Pediatr Hematol Oncol. 2013;3(1)182-186. [Crossref] [PubMed][Google Scholar]

16. Holmes L, Vanderberg j, McClarin L, Dabney K. Epidemiologic, racial and healthographic mapping of Delaware pediatric cancer. Int J Environ Res Public Health. 2015;13(1)49. doi: 10.3390/ijerph13010049 [Crossref][PubMed] [Google Scholar]

17. Amini $H$, Seifi M, Niazi-Esfyani S, Yunesian M. Spatial epidemiology and pattern analysis of childhood cancers in Tehran Iran. J Advan Environ Health Res. 2014;2(1)30-37. doi: 10.22102/jaehr.2014.40141 [Crossref][PubMed] [Google Scholar] 